\title{
The Skillful Handling of Poison: Bodhicitta and the Kleśas in Śāntideva’s Bodhicaryāvatāra
}

\author{
Stephen E. Harris ${ }^{1}$
}

Published online: 11 January 2017

(C) The Author(s) 2017. This article is published with open access at Springerlink.com

\begin{abstract}
This essay considers the eighth century Indian Buddhist monk, Sanntideva's strategy of using the afflictive mental states (kleśas) for progress towards liberation in his Introduction to the Practice of Awakening (Bodhicaryāvatāra). I begin by contrasting two images from the first chapter that represent the power of bodhicitta: the fires destroying the universe at the end of time, and the mercury elixir that transmutes base metals into gold. The first of these, I argue, better illustrates the text's predominant strategy of destroying the afflictive mental states directly by their antidotes. The second, in contrast, represents an alternative strategy in which afflictive mental states (kleśas) like anger, craving and delusion, are manipulated for liberative gain. I offer several examples of Śantideva's use of the kleśas in his text, and argue that they can be understood as a continuation of the logic of skillful means, in which destructive actions, and here destructive mental states, are used to lessen suffering. Finally, I suggest that one reason Sāntideva employs the kleśas in this way is because of his realization that many practitioners early on the bodhisattva path will lack the motivation necessary to successfully pursue the difficult training of the bodhisattva.
\end{abstract}

Keywords Śāntideva · Buddhist ethics · Mahayana buddhism · Bodhisattva · Bodhicaryāvatāra $\cdot$ Skillful means

In many ways, the eighth century Indian Buddhist monk, Sāntideva's Introduction to the Practice of Awakening (Bodhicaryāvatāra, hereafter: BCA) is a surprising text. Best known for its stunning characterizations of compassion, it also seethes with descriptions of the kleśas, the mental afflictions which include rage (krodha),

Stephen E. Harris

s.e.harris@phil.leidenuniv.nl

1 Institute for Philosophy, Leiden University, P.O. Box 9515, 2300 RA Leiden, The Netherlands 
craving (trṣngā) and delusion (moha) which bind us to samsāra. ${ }^{1}$ Strangely, Śantideva often talks of these enemies as if they were also allies; we are to rage against anger, crave the happiness of sentient beings, conjure up jealousy ( $\bar{\imath} r s y \bar{a})$ as a way of empathizing with others and so on. The great theme of the text is the development of bodhicitta, the aspiration to become a fully enlightened Buddha in order to liberate all beings from samsāra. Yet in the opening chapter Santideva characterizes its power with an image of unsurpassable violence:

Like the conflagration at the time of the destruction of the

universe, bodhicitta consumes great vices in an instant. (BCA 1:14ab, translation modified $)^{23}$

In Indian cosmology, at the end of each age the cosmos is obliterated in a storm of fire, destroying all but the subtlest realms of rebirth, after which eventually the universe regenerates. Sanntideva is describing the saving power of bodhicitta with an image that is the Indian equivalent of a universe-destroying atomic bomb.

Santideva's primary account of the protective power of bodhicitta is karmic; the bodhisattva who develops it obtains massive amounts of karmic merit (punya) (BCA 1:18-22). Śāntideva's commentator, Prajñākaramati, suggests that any remaining negative karma is so vastly outweighed by the positive effects of bodhicitta that it is unnoticeable. Significantly, Prajñākaramati also suggests that not only negative karma, but all unskillful dharmas (akuśala-dharma), that is kleśas, are destroyed by it. ${ }^{4}$ Bodhicitta, then, is the purifying agent eradicating past karma, but also the present causes of future suffering, a point nicely driven home by the image of the total obliteration of the universe. There is also, however, a hint of a second explanation of bodhicitta's power in the opening chapter:

After grasping this impure nature, bodhicitta turns it into

the priceless essence of the jewel of the conqueror.

The mercury elixir (rasajātam) has an extraordinary capacity to transmute.

\footnotetext{
${ }^{1}$ In this essay, I will primarily focus on the three kleśas of rage (krodha), craving (trṣnāa) and delusion (moha), which are held to be the deepest causes of samsāra in the Mahayana tradition, and are collectively referred to as 'the three unwholesome roots (akuśala mūla)' or 'the three poisons (trivișa).' Although in the Sikṣāsamuccaya (Śāntideva 1971) (verse 209: trans by Bendall p. 202), Śāntideva appears to reserve the term 'kleśa' for these three mental states, in the BCA he uses the term more broadly, referring for instance to lack of awareness (asamprajanya) as a kleśa in BCA 5:44. In this essay I also refer to jealousy (īrsyā) and pride (māna), which Śāntideva would likely have considered kleśas, and which in any case are caused by the three root kleśas. Thanks to Amod Lele for suggesting I explicitly treat Śāntideva's use of this term, as well as drawing my attention to both the ŚS and the BCA passages just indicated.

2 All translations are by Wallace and Wallace in Sāntideva (1997), unless otherwise noted. I give the Sanskrit throughout, however, since part of my argument depends on some of Sāntideva's specific language. Sanskrit is taken from Vaidya (1960, online version by the Digital Sanskrit Buddhist Canon), as are references to Śāntideva's commentator, Prajñākaramati.

3 yugāntakālānalavanmahānti pāpāni yan nirdahati kṣaṇena I Note the term Wallace and Wallace translate as "vices" is pāpāni, suggesting that primarily karmic demerit is being indicated.

4 Prajñākaramati makes this point in his commentary to BCA 1:14ab. pātālabhūtam sarvākuśaladharmaparyādānakaraṇatayā itill "It is like the subterranean fires in bringing about the exhaustion of all unskillful dharmas" (My translation).
} 
You should grasp firmly to the thing called bodhicitta. (BCA 1:10, my translation $)^{56}$

The metaphor is taken from alchemy, in which rasajātam is an elixir of mercury which, due to its subtle nature, penetrates base metals like lead and copper, purifying and transforming them into gold while remaining itself uncorrupted (White 1984, p. 53). ${ }^{78}$ Sanntideva's Indian commentator Prajñākaramati explains that the impure nature (pratimām) represents ordinary human nature which bodhicitta transforms into that of a Buddha. ${ }^{9}$ Part of the work that bodhicitta does, then, is to take the mental afflictions (kleśas) of ordinary human consciousness and transform them into the kuśala dharmas, or virtuous qualities that constitute a buddha's awakened mind. ${ }^{10}$

Notice the contrast between the two images. In the image of universal destruction, negative karma and its causes, the kleśas, are obliterated through the power of bodhicitta. This corresponds to the dominant method of dealing with the mental afflictions both within Sāntideva's text and in Mahayana Buddhism as a whole. Here, the mind is purified by destroying the kleśas through their antidotes (vipaksa), which are often the kuśala dharmas (skillful/virtuous qualities) that are their opposites.

\footnotetext{
5 aśucipratimām imāṃ gṛhītvā jinaratnapratimāṃ karoty anarghām | rasajātam atīvavedhanīyaṃ sudṛ̣hham gṛhṇata bodhicittasaṃjñam II I follow Śāntideva's commentator Prajñākaramati in taking "pratima" as meaning "nature" or "essence." On this point, see Hayes (2016). In his explanation of pratima, Prajñākaramati refers explicitly to the body of a human being, but in keeping with Śāntideva's text as a whole, I take it in a broader sense as also indicating the kleśas, the mental afflictions like anger and craving which are Śāntideva's main opponents, and as we will see, his sometimes allies in this text. Prajñākaramati provides evidence for this reading as well by quoting the following passage from the Gandavyūha sūtra: "For example, Oh son of a good family, there is a type of rasa called Golden Glow. A single measure of that turns one thousand measures of iron into gold. And one thousand measures of iron cannot appropriate that measure of rasa or turn it into iron. A single measure of the arising of the thought of becoming omniscient is like an alchemical liquid that can transform the mentality that contains karma and afflictions [kleśas], which is like iron, into omniscience, which is like gold, but the mentality of karma and afflictions cannot undermine the lofty aspiration for omniscience or turn it into a base mentality." (Translation by Hayes (2016), my insertion of brackets). Notice that here bodhicitta (thought of becoming omniscient $=$ ras $a=$ mercury) transforms the mental afflictions (kleśas) rather than merely the physical body.

${ }^{6}$ A difficult question of translation and interpretation in this verse is how to deal with vedhaniyam which appears to be a gerundive, and should therefore have a passive sense, making the sentence, "The mercury elixir is to be pierced." This cannot be right, however, since mercury is what does the piercing, penetrating base metal and transmuting it into gold. Instead, I follow Prajñākaramati (and Hayes 2016) in taking vedaniyam in an active sense, meaning that which pierces, or in the present context, that which transmutes. See also a very helpful discussion on the Indology Listserve beginning on July 6, 2014 ("Alchemy metaphor" posted by Christopher Wallis.) http://listinfo.indology.info/.

${ }^{7}$ In later tantric theory, mercury is equated with the sexual fluids transferred from teacher to student. See White (1996), especially chap 10. According to Wangchuk (2007, pp. 217-225), bodhicitta itself is sometime equated with semen, or menstrual blood in Buddhist tantric texts. It is safe to say, then, that this verse has deep tantric resonances, although I am not arguing that these are intended by Śantideva; following Prajñākaramati (and Hayes 2016), I take its primary reference to be alchemic. See also Gray (2001, Chap. 2.1) for additional references to Mahayana texts employing the image of mercury to represent bodhicitta.

${ }^{8}$ On the incorruptibility of bodhicitta, see BCA 1:12.

${ }^{9}$ See Prajnakaramati's commentary to BCA 1:10a. amedhyapratimām imām manusyādikalevarasvabhāvām taddhātukām tatsvabhāvāml The impure image, whose essence (svabhāva) is the body of a human being and so on. Essence (svabhāva), here, means nature (dhātuka).

${ }^{10}$ See Gray (2001, pp. 87-88) for his treatment of BCA 1:10. On this, see my footnote 40.
} 
Bodhicitta as mercury elixir, by contrast, does not destroy the kleśas, but takes them up for purification and transformation into liberation itself. This, I will argue, better represents an alternative strategy of dealing with the kleśas found throughout the BCA, in which Śāntideva manipulates their power for liberative gain.

\section{What is Bodhicitta?}

It is easy to give a rough pass at what Sanntideva means by bodhicitta in the BCA. It is the thought or intention (citta) to attain the full awakening (bodhi) of an enlightened Buddha in order to most effectively liberate all sentient beings from samsāra. ${ }^{11}$ Performing this task requires the development of the six perfections (pāramitās) of generosity (dāna), ethical restraint (śilla), patience (kșānti), effort (vīrya), concentration (dhyāna) and wisdom (prajñā), four of which receive their own chapter in Śantideva's BCA. ${ }^{12}$ Sanntideva's lengthy treatment of wisdom in the ninth chapter, and the extensive meditations on compassion given in the eighth chapter also suggest that Sāntideva accepts the Mahayana position that bodhicitta involves the union of compassion and wisdom. There are a number of technical questions left unresolved by this rough characterization. In Abhidharma thought, compassion (karuñā) and wisdom (prajñā) are caitasika, mental states that accompany a moment of sensory or conceptual awareness (citta). ${ }^{13}$ In Abhidharma terminology, therefore, we can ask whether the term bodhicitta refers to the conscious awareness itself (citta) which is accompanied by these distinct mental factors (caitasika), or is a conceptual conjunct of all these factors. A third possibility, held in some Mahayana texts, is that it is the mental factor (caitasika) of intention $($ cetana $)$ to attain enlightenment for the sake of all beings, which is accompanied by these other mental factors. ${ }^{14}$

The BCA is not composed primarily with Abhidharmic technical precision, however, and Śāntideva gives no answer to these questions. For our purposes, we

\footnotetext{
11 Although this is the usual Mahayana understanding of the term, see Wangchuk (2007, pp. 129-133) for a careful treatment of possible resolutions of the compound bodhi-citta.

12 Patience, effort, concentration and wisdom each receive a chapter in the BCA. Arguably, the chapter dedicated to introspection (samprajanya) is intended as a chapter on ethical restraint (Crosby and Skilton p. xxxiv). The concluding chapter, in which the bodhisattva dedicates his practices for the benefits of all beings, can be interpreted as a chapter on generosity.

13 The various Abhidharma systems use different terminology to describe these mental states. Asanga, for instance, calls compassion (karuṇā) "harmlessness" (avihimssā) (Asanga 2001, p. 11), and prajñā is referred to as "non-delusion" (amoha) (10). All Abhidharma systems, to my knowledge, recognize both as mental factors (caitasika), but vary in how they integrate them into their list of factors.

14 For instance the Mahāyānasūtrālamkārabhāșya defines the arising of the thought of awakening (cittotpāda), which is almost certainly a synonym for bodhicitta, as the intention (cetanā) to attain awakening for "great enlightenment" and "the fulfillment of others" [4:1, translation by Thurman (2004, p. 31).] The same explanation is given in the Abhisamayālamkāra (Sparham 1992, p. 228). On this definition, see Wangchuk (2007, p. 152), and see his chap five section four and chapter eight for summaries of a range of positions held on the meaning of bodhicitta and its synonyms in Mahayana sutras. Ultimately, he claims that Mahayana texts differed as to whether bodhicitta is a moment of main consciousness (citta), an associated mental factor (caitasika) such as intention (cetanā), or a combination of both (197).
} 
can simply note that when bodhicitta is in play, both factors of wisdom and compassion must be present, although we can leave unanswered the question of whether bodhicitta itself is one, or even both of these factors. This will be sufficient for examining its transformative power, which is my main interest here.

\section{Poison and Its Antidotes}

The primary strategy Śantideva uses to confront the kleśas in the BCA is by destroying their manifestations as quickly as possible. This corresponds to the dominant strategy in the mainstream Buddhist tradition, as exemplified for instance in right effort (samyagvyāyāma), the sixth part of the eightfold path, in which kleśas are prevented from arising and, once arisen, are dissolved (Bodhi 2000, S v 2). A common way of doing this is by using contemplations that cause the arising of a virtuous mental quality (kuśala-dharma) that, as the antidote (vipakṣa) to the kleśa, destroys it. To use a prominent example within Śāntideva's text, patience (kșānti) is the antidote to anger (krodha); when one is present, the other cannot exist, and so causing patience to arise destroys anger. Sāntideva's sixth chapter provides numerous meditations designed to make patience arise, such as the following:

If there is a remedy, then what is the use of frustration?

If there is no remedy, then what is the use of frustration? (BCA 6:10) ${ }^{15}$

Patience, which arises upon contemplating the futility of anger, destroys it. This method dominates the second through ninth chapters of the BCA, in which effort (virya) dissolves sloth (älasya, BCA 7:2), mindfulness and introspection act as antidotes to breaking ethical discipline (BCA chap 5) and so on. The strategy is complementary to the BCA's emphasis on bodhicitta and its key components of wisdom and compassion, since both of these weaken or destroy delusion (moha) and anger (krodha) respectively. It does not, however, correspond very closely to the metaphor of bodhicitta as the mercury elixir that transmutes rather than annihilates the kleśas. This at least invites us to look for a distinct approach employed in the BCA.

\section{The Skillful Handling of Poison}

While Sanntideva's antidote strategy referred to above weakens and eliminates the kleśas directly, there is a less pervasive but still frequent group of meditations that seek to if anything intensify our experience of the kleśas. These meditations invoke all three of the root kleśas of anger (krodha) craving (trṣnā) and delusion (moha) and by far the most frequent strategy employed is to waken and redeploy their energy into liberative purposes. An obvious example is the redirection of anger towards the defilements, which would include of course anger itself.

I shall be tenacious in this matter; and fixed

\footnotetext{
15 yady asty eva pratīkāro daurmanasyena tatra kim I atha nāsti pratīkāro daurmanasyena tatra kim II.
} 
on revenge, I shall wage war, except

against those mental afflictions that are related

to the elimination of mental afflictions. (BCA 4:43) ${ }^{16}$

Disregarding the principal cause, such as a stick and the like,

if I become angry with the one who impels it, then it is

better if I hate hatred, because that person is also

impelled by hatred. (BCA 6:41) ${ }^{17}$

Within the BCA, the most frequent example of this strategy is the channeling of the energy from aversion, which arises when we contemplate death and the possibility of horrible rebirths. The strategy becomes particularly explicit in the seventh chapter, in which fear (bhaya/trāsa) of death and negative rebirths is used to stimulate the arising of the perfection of effort (virya), providing the motivation to progress along the bodhisattva path. ${ }^{18}$

Tormented by the recollection of your own vices, hearing the sounds of hell, and befouling your body with excrement out of fear, what will you do when you are so terrified?

Realizing "I am like a live fish," your fear is appropriate now.

How much more when you have committed vices and face the intense suffering of hell? (BCA 7:10-11) ${ }^{19}$

What is particularly intriguing about these passages is that all such fear itself arises only because of delusion (moha). In part, this is because fear of death is predicated upon the mistake of believing there is an enduring being that can live and die. ${ }^{20}$ Sāntideva's own way of developing this point, however, is to emphasize the illusion-like nature of the being that fears.

If there were something called "I," fear could come from anywhere.

If there is no "I," whose fear will there be? (BCA 9:56) ${ }^{21}$

\footnotetext{
16 atra grahī bhaviṣyāmi baddhavairaś ca vigrahī I anyatra tadvidhāt kleśāt kleśaghātānubandhinaḥ ॥.

17 mukhyam daṇ̣̂ādikam hitvā prerake yadi kupyate I dveșeṇa preritah so 'pi dveṣe dveșo 'stu me varamll.

18 Numerous descriptions of the horrors of death can be found throughout the BCA. See in particular BCA 2:28-65. See Garfield (2010) and Brons (2016) for additional treatments of the importance of fear (bhaya and/or samvega) and meditations upon death in Śāntideva's BCA. See Giustarini (2012) and Brekke (2002, Chap. 5) regarding the positive motivational power of fear (bhaya and/or samvega) in early Buddhist texts.

19 svapāpasmṛtisaṃtaptah śṛ̣van nādāṃś ca nārakān I trāsoccāraviliptāñgo vihvalaḥ kiṃ kariṣyasi ॥l. jīvamatsya ivāsmīti yuktạ̣ bhayam ihaiva te I kị̣ punạ̣ kṛtapāpasya tīvrān narakaduḥhataḥll.

${ }^{20}$ On this point, see Buddhaghosa (1991, p. 555). "[The deluded person] is confused about death, instead of taking death thus, 'Death in every case is break-up of aggregates', he figures that it is a [lasting] being that dies, that it is a [lasting] being's transmigration to another incarnation, and so on."

21 yad duhkhajananam vastu trāsas tasmāt prajāyatām I sūnyatā duhkhaśaman̄̄ tatah kim jāyate bhayam ॥ I follow the numbering of Wallace and Wallace (which matches Crosby and Skilton) for the verses in BCA chap 9. As Crosby and Skilton explain (1995, pp. 113-114), this corrects for a scribal error which was noticed, but not corrected by De la Vallée Poussin and Vaidya in their editions.
} 
Fear of death and rebirth, then, in addition to representing an example of aversion, is itself a result of the kleśa of delusion (moha) which takes transient psycho-physical events to be an enduring self. The insight that Śantideva manipulates to such devastating effect throughout the BCA is that these pockets of defiled energy, themselves predicated upon cognitive mistakes, can be redeployed against that very source of the cognitive error. Sāntideva spurs deluded beings into greater heights of imaginary terrors for the sake of salvation. ${ }^{22}$ The strategy is particularly apparent with death, but actually all defiled energy arises because of cognitive error. It is because we see beings as enduring entities, for instance, that anger can arise towards them. ${ }^{23}$

The use of the power of attachment (trṣna $)$ is less pronounced in the BCA. In one verse, Santideva talks about craving (tṛṣnā) to bring about the benefit of others (BCA 8:109). But this strategy is most obvious in the first chapter, where Śantideva extols the root bodhisattva virtue of bodhicitta by listing its many benefits for the bodhisattva himself. ${ }^{24} \mathrm{He}$ states that we should develop bodhicitta because it quickens our own path to liberation by purifying past negative karma (BCA 1:1314), increases our supply of karmic merit (BCA 1:17-22) and makes us esteemed throughout the universe (BCA 1:9). ${ }^{25}$

As for ignorance (moha), since it is the root of both attachment and aversion, Santideva's use of the other defilements implicitly depends on the manipulation of ignorance as well. There are also places in the text where Sāntideva uses false conceptualization directly as a liberative aid. Perhaps most intriguing is the series of verses in the eighth chapter on the theme of exchanging oneself with others. In these series of meditations, the practitioner imaginatively takes up the perspective of another person who is either inferior, equal or superior to himself, and imagines how they would contemplate him. Here, not only does Śantideva claim we should use false conceptualization to enact this imaginary transformation (BCA 8:115), but he even suggests we develop negative emotional responses, including envy and pride (īssya,$m \bar{a} n a)$ as a way of understanding how the other person ordinarily feels about us.

Placing your own identity in inferior ones

and placing the identity of others in your

own self, cultivate envy and pride with the

mind free of discursive thoughts. (BCA 8:140)

\footnotetext{
22 Brekke (2002, Chap. 5) also emphasizes the use of fear (bhaya) as a motivation to attain the state of liberation/fearlessness in Buddhist texts, including Śāntideva's BCA. See especially Brekke (2002, pp. 80-82).

23 Śāntideva provides multiple examples of this last insight in chapter six of the BCA.

24 See Jenkins (1999) and Harris (2014) for studies of the relationship between altruism and self-interest in the BCA.

25 This, of course, connects the bodhisattva's initial motivation for liberation with that proposed by early Buddhist texts stressing liberation for oneself. Śāntideva himself draws this connection in BCA 1:20. What deserves emphasis is the almost complete neglect of compassion itself as a motivation for taking up the bodhisattva path until the eighth chapter of the text. See Anālayo (2010, Sect. 1.2) for a detailed description of self-interest as the motivation of the Buddha, as portrayed in the early Buddhist canon.
} 
He is respected, not I. I am not wealthy as he is. He is praised, while I am despised. I am unhappy, while he is happy. (BCA 8: 141)

The point of the meditation is to help the meditator to gain empathy for the inferior person through imaginatively experiencing the jealously and envy they feel towards him. ${ }^{27}$ Similar meditations follow, designed to awaken empathetic understanding of one who is our equal, or is superior to us. What deserves emphasis here is that if we take the language Śantideva uses seriously, it is the actual kleśas that are generated and manipulated as a means of expanding our empathy. We can mark here even more strongly the contrast with the antidote strategy, in which it is the kuśala-dharmas, rather than the kleśas, that are nurtured. Of course, all such handling of the negative mental states can be seen as strategic and provisional; it is because we are infected with anger, delusion, craving and so on that Santideva finds it necessary to employ their energy. Still, the fit here is much closer to the description of bodhicitta as mercury elixir which transmutes rather than destroys the base metals which are the kleśas.

Śāntideva offers relatively little explicit reflection on his strategy of deploying the kleśas for liberative gain. ${ }^{28}$ Nevertheless, it can be interpreted as a continuation of the logic of skillful means (upāya-kauśalya), in which the bodhisattva violates precepts forbidding physical or verbal harm in cases where it is clear that doing so will prevent great suffering. One of the most influential lists of traditionally forbidden actions in Buddhist texts are the ten virtuous courses of action (dasakusalakammapatha), which are themselves avoidances of ten destructive actions, divided into the negative physical actions of killing, stealing and sexual misconduct; the negative verbal ones of lying, divisive speech, harsh speech and gossip; and the mental actions of malicious thought, covetousness and false views. Asanga, in his explanation of skillful means, gives examples in which the bodhisattva violates each of the first seven items on the list. For instance, he steals back religious items that were taken by thieves from a temple, uses slander to divide disciples from corrupt teachers, speaks harsh words to frighten people into following Buddhist teachings, and most famously, kills a thief on a ship who had been planning on slaughtering everyone on board (Asangga 1986, p. 69a3). In each example, Asanga is clear that two elements are necessary for making these violations of prohibitions permissible. First, the bodhisattva must be motivated by compassion for the wrongdoer, and second, the bodhisattva must have the wisdom

\footnotetext{
26 BCA 8:140-141: hīnādiṣv ātmatām kṛtvā paratvam api ca atmani । bhāvayerṣyāṃ ca mānam ca nirvikalpena cetasā II eșa satkriyate nāham lābhī nāham ayạ̣ yathā I stūyate 'ham aham nindyo duhḳhito 'ham ayạ̣ sukhī || BCA 8:115:yathātmabuddhir abhyāsāt svakāye 'smin nirātmake I pareșv api tathātmatvam kim abhyāsān na jāyate I Just as the notion of a self with regard to one's own body, which has no personal existence, is due to habituation, will the identity of one's self with others not arise out of habituation in the same way? (Translation by Wallace and Wallace in Śāntideva (1997)). Śāntideva seems to be redeploying our habitual processes of false identification as an aid in meditational identification with others. In other words, he is using the processes of ignorance (moha) as part of a meditation to develop compassion.

27 Compare Gomez (1973, p. 364).

28 BCA 6:41, cited above, is an exception, although no extended explanation of his motivation is given here as well.
} 
to understand that the action in question will be beneficial. ${ }^{29}$ Notice the connection with bodhicitta, since only a high level bodhisattva, advanced in both wisdom and compassion, is able to employ skillful means in these ways.

Asanga does not recommend any violation of the mental courses of negative action, of malice, covetousness and wrong views. These are intrinsically negative, leading to harmful karmic consequences, a deepening propensity to experience the mental state in the future, as well as causing the agent to perform the harmful physical and verbal actions listed as the first seven courses of negative action. For Asanga, it is only because the bodhisattva can perform the seven forbidden actions without these kleśas arising that he is allowed to do so. The bodhisattva steals, kills and so on motivated not by covetousness and malice, but by compassion.

In these ordinary cases of skillful means, then, compassion protects the bodhisattva's mind from the arising of craving and hatred when actions like theft and killing are committed. What we find in Śantideva's BCA, I am suggesting, is an extension of this logic in which the incredible power of bodhicitta is seen as capable of shielding the bodhisattva's mind from the harmfulness of the kleśas themselves. Now the bodhisattva, protected by the incorruptible bodhicitta, which represents the strongest grade of compassion fused with wisdom, can handle even the kleśas with immunity, manipulating skillfully the three negative mental courses of action which even Asanga will not allow the bodhisattva to touch.

\section{Transmuting Poison}

In the last section, I suggested that Sanntideva's employment of the kleśas can be seen as an extension of the logic of skillful means, with bodhicitta and its twin aspects of compassion and wisdom protecting the agent from the harmful effects of the kleśas whose power is being harnessed. What has yet to be considered is how bodhicitta enacts its protective properties. As usual, Śāntideva's most explicit explanation is karmic; massive amounts of meritorious karma (punya) result from generating bodhicitta, which presumably far outweigh any negative consequences of the kleśas themselves (BCA 1:13-14, BCA 1:17-22).

I offer, however, two additional possible explanations, both of which are in keeping with reoccurring themes and strategies in Sāntideva's text. Each depends for its efficacy on one or both of bodhicitta's twin aspects of wisdom and compassion, and therefore partly explains the link between bodhicitta and the kleśas in the BCA. The first depends on the insight that realizing emptiness results in a psychological fluidity in our interactions with any constituents of and experiences within conventional reality. ${ }^{30}$ Santideva explicitly employs this strategy frequently; for instance, realization of selflessness dissolves the fear of death (BCA 9:56),

\footnotetext{
29 Asanga gives these conditions by having the bodhisattva realize that breaking the prohibition will prevent the recipient from experiencing the negative consequences of his misdeed, after which the bodhisattva recognizes the planned skillful means as a virtuous or indeterminate act. He then completes the act motivated by compassion. See Asanga (1986, p. 69.a3).

${ }^{30}$ Lele (2007, pp. 71-72) makes a related point, emphasizing that for Śāntideva, insight into emptiness lessens emotional attachment to objects.
} 
loosens our aversion to experience of pain (BCA 9:88-91) and eliminates all attachment to our body (BCA 7:25-26). ${ }^{31}$ What is distinctive about this strategy is that it allows the bodhisattva to continue to interact with the world, conceiving of himself as a conventionally unified being, but with a psychologically transformed mind that is resistant to the power of craving and hatred. In the same way, I am suggesting, realizing the emptiness of the kleśas may result in a sense of disconnection and fluidity in response to their awful power. This allows the bodhisattva to use them without falling under their sway.

Such a strategy makes good sense of Sanntideva's use of the kleśa of delusion, in particular in the strategy surveyed above in which he calls up jealousy and pride as a way of deepening empathy towards others (BCA 8:140). ${ }^{32}$ Obviously, here, the intention cannot be to generate a strong enough kleśic response that we become deeply jealous of ourselves. Plausibly, understanding the emptiness of the kleśas generated, as well as the falsity of the processes of reification, allows a playfulness in which the bodhisattva can examine manifestations of the kleśas without being bound by their power. It is less clear that this strategy can satisfactorily explain Santideva's rechanneling of afflictive motivational energy, however. The problem here is that it would require simultaneously weakening the force of the fear of death and so on, even while drawing on the strength of that fear to propel us towards liberation.

The second strategy is modeled more closely on the alchemic image in which base metal is transmuted into gold. The idea here is that the energy of the kleśas, though defiled, when combined with bodhicitta will naturally fuel its own destruction and replacement by the force of the kuśala dharmas themselves. As an intuitive example of this strategy, consider how anger might be used in the service of compassion. Imagine a parent who becomes furious at a school official for their unjust treatment of the parent's child. In this case, the parent's deepest motivation is the compassionate wish to remove his child's suffering; nevertheless, out of frustration at the official, anger in its negative sense of wishing to do harm, has arisen. ${ }^{33}$ Provisionally, the anger benefits the parent, providing extra energy and courage to confront the official. Nevertheless, if the parent's deepest motivation really is compassion, once the problem has been rectified the anger will simply

\footnotetext{
31 "If there were something called I, fear could come from anywhere. If there is no I, whose fear will there be?" (BCA 9:56). "If suffering truly exists, why does it not oppress the joyful? If delicacies and the like are a pleasure, why do they not please someone struck by grief and so forth? If it is not experienced because it is overpowered by something more intense, how can that which is not of the nature of experience be a feeling? [Objection:] Surely there is suffering in its subtle state while its gross state is removed. [Madhyamika:] If it is simply another pleasure, then that subtle state is a subtle state of pleasure. If suffering does not arise when the conditions for its opposite have arisen, does it not follow that a feeling is a false notion created by conceptual fabrication?" (BCA 9:88-91). "At the beginning, the Guide prescribes giving vegetables and the like. One does it gradually so that later one can give away even one's own flesh. When insight arises that one's own flesh is like a vegetable, then what difficulty is there in giving away one's flesh and bone?" (BCA 7:25-26). (All translations by Wallace and Wallace in Śāntideva (1997)).

${ }^{32}$ Notice as well that Sanntideva's instructions are to perform this meditation with a mind free of discursive thought (nirvikalpa).

${ }^{33}$ The wish to harm another is the usual Abhidharma definition of anger (krodha). See for example Asanga (2001, p. 15).
} 
dissolve and all future action taken will be motivated by compassion directly. In this example, the dangerous energy of anger can be harnessed with relative safety since it will gain no deep hold on the parent's mind, being integrated into his overall compassionate motivation for the child's well-being.

We can imagine a similar strategy at work in reference to several of Śāntideva's invocations of the power of the kleśas, that were discussed in the last section, such as craving (trṣna $)$ for the well-being of others (BCA 8:109). A parent may have both love (maitri $)$ as a pure uncontaminated wish for their child's happiness, mixed with craving (trṣna $\bar{a})$ in which the child's success is desired to fulfill the parents own wishes. Both pure and deluded motivations may, in the short term, lead the parent to take steps that genuinely support the child's development. Likewise, the lower level bodhisattva may have generated an altruistic wish for the happiness of others, but may also crave the well-being of sentient beings as a result of his selfish attachment to them and even attachment to his own achievements as a bodhisattva. As a result of both motivations, he commits to developing wisdom and compassion and progressing further along the bodhisattva path. Wisdom, when sufficiently strengthened, will act as the antidote to the craving which partly motivated its development, leaving the strengthened force of compassion to further inspire progression towards Buddhahood.

Likewise, a smooth progression from craving (tṛṣna ) to genuine love (maitrī) for oneself and others can explain the BCA's early chapters' emphasis on entering the bodhisattva's path out of motivation for one's own well-being (BCA 1:9, 1:13-14, 1:17-22). Early on, karmic reward for one's own sake may be the bodhisattva's primary motivation; as compassion develops, however, this will shift naturally to genuine concern for others. Likewise, in the last section we saw that Sanntideva utilizes the fear of death and bad rebirth to motivate a deeper commitment to the bodhisattva path (BCA 7:10-11). All such fear, however, is predicated on the mistaken belief that there are enduring beings that die and suffer torture. Once wisdom frees the bodhisattva from these delusions, it will eliminate aversion and the fear which arises out of it; until then, the bodhisattva can use its energy for his gain.

Another example of Śāntideva's use of this strategy is found by contrasting a set of verses from the third and fourth chapters on the motivation to engage in the bodhisattva path. In the twenty-third verse of the third chapter, the bodhisattva takes the bodhisattva vow. ${ }^{34}$ This is preceded by a stunning series of aspirations expressing his dedication to liberating others from samsāra. The bodhisattva is to be a "protector" of the "protectorless" (BCA 3:17), a "lamp for those who seek light" (BCA 3:18), a "bridge" or "ship" allowing beings to "crossover" to the shores of nirvana (BCA 3:17) and so on. The verses suggest that the deepest feelings of compassion possible inspire and accompany the bodhisattva's powerful pledge.

It is somewhat jarring, then, to find these beautiful aspirations followed in the next chapter by threats of the horrible karmic consequences of breaking one's bodhisattva commitment.

If, upon making such a promise, I do not put it into action,

\footnotetext{
34 "So I myself shall generate bodhicitta for the sake of the world; and so I myself shall properly engage in those practices."(BCA 3:23, translation modified)
} 
then having deceived those sentient beings, what destiny shall I have? (BCA 4:4)

It has been said that a person who intended to give away even a tiny thing but does not do so becomes a preta. (BCA 4:5)

Then all the more so, having deceived the entire world after loudly and sincerely inviting it to unsurpassable happiness, what state of existence shall I have? (BCA 4:6)

Therefore, I should respectfully act in accordance with my commitment. If I do not make an effort now, I shall go from lower to lower states. (BCA 4:12) ${ }^{35}$

The promise in verse four is of course the bodhisattva's commitment to attain full awakening in order to liberate all beings from samsāra. The preta, referred to in verse five, is a kind of ghost that wanders the earth famished with hunger or thirst. The consequences for breaking the bodhisattva vow, alluded to in verse twelve as "lower states," are rebirth as a preta or in the hell realms. In these verses, then, Santideva motivates the bodhisattva to keep his commitment by appealing to the horrendous karmic consequences of breaking it. Apparently, the bodhisattva's feeling of compassion for others has taken a back seat to a frenzied concern for his own well-being. How are we to reconcile these sets of verses?

The solution, I think, must be that deep compassion is generated during the taking of the vow, but its force is too weak and the stranglehold of the mental defilements (kleśas) too strong for it alone to provide enough motivational power to make significant progress along the difficult bodhisattva path. Provisionally, then, craving, egoistic concern and aversion are redeployed against themselves to solve this motivational lack. Bodhicitta, in its aspect of compassion, provides the overarching motivation to liberate sentient beings, but borrows strength from the kleśa of aversion, here represented as fear of negative rebirths, in order to achieve its massive task. Moreover, as progress is made on the bodhisattva path, eventually fear of negative rebirths will be eliminated. In part this is because all negative karma that would lead to such a rebirth will be purified by the development of bodhicitta, and in part because once the illusion of an enduring self is overcome, death and rebirth are no longer feared. ${ }^{36}$ Bodhicitta allows us to temporarily incorporate the kleśas into the path, but also protects us from their power.

These observations help answer the related question of why Santideva risks the redeployment of the kleśas' energy at all. Given their extremely pernicious effects, why does Śantideva not limit himself to using only the antidote strategy in which

\footnotetext{
35 yadi caivaṃ pratijñāya sādhayeyaṃ na karmaṇā I etāṃ sarvāṃ visaṃvādya kā gatir me bhaviṣyati ॥ manasā cintayitvāpi yo na dadyāt punar narạ̣ I sa preto bhavatīty uktam alpamātre 'pi vastuni || kim utānuttaram saukhyam uccair uddhuṣya bhāvatah I jagat sarvạ̣ visaṃvādya kā gatir me bhavișyati ॥ (BCA 4:4-6) tasmād yathā pratijñātạ̣ sādhanīyạ̣ mayādarātl nādya cet kriyate yatnas talenāsmi talạ̣ gatah II (BCA 4:12).

36 "If there were something called I, fear could come from anywhere. If there is no I, whose fear will there be?" (BCA 9:56)
} 
the kleśas are destroyed as quickly as possible by their opposites? The answer is suggested most strongly in the first chapter of the BCA.

Just as lightning illuminates the darkness of a cloudy night for an instant, in the same way, by the power of the Buddha, occasionally people's minds are momentarily inclined toward merit.

Thus, virtue is perpetually ever so feeble, while the power of vice is great and extremely dreadful. If there were no bodhicitta, what other virtue would overcome it? (BCA 1:5-6, translation modified) ${ }^{37}$

In the conceptual background of these verses lies the full range of terms denoting psychological bondage to the mechanisms of rebirth in samsāra, including the habitual tendencies (anuśaya) for kleśas to arise again and the influx of the cankers (āśravas) of sensual desire, desire for existence, false views and ignorance, which infiltrate our cognitive systems. The verses suggest that the nudge of a Buddha alone pushes us far enough from this samsāric psychological slime to experience a moment when a commitment to liberation is possible. Nevertheless, mired as we are in the muck of craving and delusion, slippage back into habitual patterns is almost inevitable, a theme which becomes explicit in the fourth chapter of the text.

I have somehow obtained the advantageous state that is very difficult to achieve, and though aware of that, I am led back to those same hells.

I have no will in this matter, as if bewitched by spells. I do not know by whom I am bewitched or who dwells inside me. (BCA 4:26-27) ${ }^{38}$

The reference in the second verse is to the kleśas which pull the bodhisattva back into habitual patterns of vice despite his commitment to the bodhisattva path. Given that the kuśala dharmas are so weak at the beginning of the path, effort (virya) compassion (karunāa) and these other virtuous motivational factors will be almost nonexistent. Energy to commit to the path must come from somewhere. What can be a more powerful motivation for deluded beings like us than dread terror of nonexistent death, rage against hatred itself and greedy clinging to the goal of attaining full Buddhahood? A bodhisattva developing skillful means must use whatever resources are available to him, even if they turn out to be the very enemies that he has vowed to ultimately destroy. ${ }^{39}$

\footnotetext{
37 rātrau yathā meghaghanāndhakāre vidyut kṣaṇaṃ darśayati prakāśam I buddhānubhāvena tathā kadācit lokasya puṇyeṣu matị̣ kṣaṇaṃ syātll tasmāc chubhạ̣ durbalam eva nityaṃ balạ̣ tu pāpasya mahatsughoram I taj jīyate 'nyena śubhena kena saṃbodhicittạ̣ yadi nāma na syātll.

38 kathaṃcid api samprāpto hitabhūmiṃ sudurlabhām I jānann api ca nīye 'haṃ tān eva narakān punạ̣ ||26|| atra me cetanā nāsti mantrair iva vimohitaḥ I na jāne kena muhyāmi ko 'tra antar mama tișthati \|27\|.

39 Paul Williams also recognizes that the early chapters of Śāntideva's BCA often emphasize self-benefit, while the later chapters emphasize greater concern for others (Williams 1998, pp. 28-29). Williams suggests that this movement from egoism to altruism is motivated by rational analysis; in particular, he considers in great detail a series of verses in the eighth chapter of the BCA in which Śantideva claims
} 
In this section I have given three explanations for how bodhicitta allows the bodhisattva to redeploy the energy of the kleśas while protecting her from its power. Śantideva's most explicit explanation is karmic; vast oceans of positive karma (punya) are accumulated by the generation and strengthening of bodhicitta, which will counteract eons of past negative karma. I have also reconstructed two additional strategies, each of which depends upon one or both of bodhicitta's twin aspects of wisdom and compassion. First, as wisdom is strengthened, the bodhisattva develops a psychological flexibility in his response to the elements of experience. This allows him to conjure up mental afflictions without becoming prey to their power. Second, bodhicitta in its aspect of compassion provides the overarching motivation to achieve enlightenment, but is initially too weak to overcome the force of the kleśas. Therefore, the energy of the kleśas is provisionally incorporated into the path. As the bodhisattva develops, these kleśas are themselves destroyed by wisdom and the other virtues (kuśala-dharma) ${ }^{40}$

It should be clear why I find the second and third of these strategies a relatively close fit with the alchemic metaphor. The kleśas are handled by the bodhisattva who, protected by the mercury elixir of bodhicitta with its aspects of wisdom and compassion, is able to manipulate their power. The analogy breaks down in that the kleśas are not literally turned into the kuśala dharmas; they are destroyed, but in a way in which the kuśala dharmas arise naturally out of their destruction. Nevertheless, the fit between the alchemic metaphor and Śāntideva's use of defiled energy is much closer than the image of universal destruction, which acts as a metaphor for the complementary but distinct strategy of the immediate elimination of the kleśas.

We should also notice that the antidote and transmutation strategies of dealing with the kleśas are deeply entwined. Even when the kleśas are simply destroyed by their antidotes, it is often afflicted energy, such as the fear of death, which Śantideva uses to develop the appropriate antidote, such as the example treated above in which fear of death and rebirth is incorporated into the generation of effort (virya). ${ }^{41}$ Moreover, in the tantric-like strategy of turning the kleśas against themselves,

\section{Footnote 39 continued}

that, once selflessness has been accepted, prioritizing one's own well-being over others is irrational (Williams 1998, Chaps. 2 and 5). Williams' approach is, I think, complementary to the one I take here. The transition from egoistic to altruistic language in the BCA is explained both by the bodhisattva's recognition of the irrationality of selfish behavior, as well as his development of sufficient other-regarding motivation to make further progress along the path. For Williams' treatments of Śāntideva's arguments, see Williams (1998, Chaps. 2 and 5). See also philosophical responses to Williams by Pettit (1999), Siderits (2000) Schmithausen (2007) and Harris (2011).

${ }^{40}$ Compare Gray's explanation of how bodhicitta transmutes the kleśas. "What is transformative here is one's intention; the expansion of one's sense of self, with a concomitant desire to help others in the same way that an ordinary person seeks to benefit himself, acts as a catalyst, so to speak, transforming the negative emotions which are basically epiphenomena of a selfish, self-centered perspective, into motivating energies; this alchemy then aims to transform the passions into compassion. Compassion thus has the capacity to transform the passions through a process of reorientation" $(2001$, p. 90). I think this is largely right, but it does not yet explain how the energy of the "negative emotions" is harnessed. I have offered a possible solution here.

41 This is particularly apparent in the early verses of chapter seven of the BCA, which is devoted to nurturing effort (vīrya). See BCA 7:1-7:14. 
eventually the kleśas are destroyed by the power of the antidotes of wisdom and compassion which they have helped to strengthen. Nevertheless, the strategies can be distinguished as distinct approaches to the kleśas, in respect to whether the dangerous power of the kleśas is dissolved as quickly as possible, or is seen as a powerful resource to be provisionally redeployed.

Śāntideva's strategy of utilizing afflicted energy bears a resemblance to one of the best known features of Buddhist tantra, in which the power of desire (käma) is used in the service of liberation. ${ }^{42}$ Nevertheless, tantra is a complex phenomena, and arguably the most distinctive elements of the tantric tradition are absent from the BCA. Most obviously, this includes visualization of oneself as an already fully awakened Buddha. Missing as well is the identification of antinomian substances such as corpses, feces, and repulsive body parts, as pure, indicating nonduality (Gray 2001, pp. 79-86; Williams and Tribe 2000, pp. 235-237). Although all these items reoccur frequently in the BCA, Santideva's use of them is modeled on early Buddhist and non-tantric Mahayana meditations, in which repulsive objects are used to lessen lust and motivate dedication to the Buddhist path. ${ }^{43}$ My study, therefore, can be said to draw attention to tantric elements within Śāntideva's text only in a limited sense. Moreover, I have already argued that Sāntideva's use of the kleśas can be viewed as an extension of the classic Mahayana doctrine of skillful means. For this reason, I see his strategy of utilizing the kleśas as illustrating a point of continuity between mainstream and tantric Buddhist traditions, more than it indicates a distinctly tantric element within the BCA. ${ }^{44}$

\footnotetext{
42 One of the best known statements of this theme is found in the Hevajra Tantra: "[T]he world is bound by passion, also by passion it is released" (II: ii, 51: Snellgrove 1959, p. 93). I take this example from Williams and Tribe (2000, p. 202). See Gray (2001, pp. 25-39) for a useful summary of influential definitions of tantra which I found helpful in preparing this section. Excellent introductions to tantra include Davidson (2002), Williams and Tribe (2000, Chap. 7) and Cozort (2005).

43 Depictions of death are a frequent theme of many of the chapters of the BCA, but perhaps the most striking example is a set of forty or so verses (BCA 8:30-8:70) in which Śāntideva contemplates corpses in a charnel ground. Within this long passage, a subset of ten verses is dedicated to examining the filth of the human body (BCA 8:53-62). Santideva notes repulsive parts of the body (blood, entrails, phlegm, urine, pus etc) in BCA 5:65 and again in an argument for selflessness in BCA 9:57-59. Particularly influential examples of the contemplation of foul body parts and corpses in the early Buddhist tradition are found in the Foundations of Mindfulness sutta (Ñānamoli and Bodhi 1995, pp. 147-149: M i 58-60).

44 We should also keep in mind that the Mahayana itself is largely continuous with early Buddhist traditions (Harrison 1987; Samuels 1997; Silk 2002). Likewise, certain early Buddhist texts also give a provisionally positive role to certain kleśas, such as craving (tṛ̣nā/taṇhā) directed towards liberation. Matthews (1983, p. 80) draws attention to a passage in the Nettippakarana in which skillful and unskillful kinds of craving are distinguished, with the skillful kind being craving for release from samsāra. See Nettippakaraṇa 87 (Ñāṇamoli 1977, p. 121) and Matthews (1983, pp. 80-88). Studies which stress continuity between Buddhist tantric texts and non-tantric Mahayana themes include Gray (2001) and Wedemeyer (2013).
} 


\section{Conclusion}

In this study, I have argued that the image of alchemic transmutation that Sanntideva employs at the beginning of the BCA need not be assimilated to the ordinary strategy of eradicating the kleśas by means of the antidotes. Instead, we can read it as illustrating Śantideva's use of the kleśas for liberative purposes. I suggested that such a strategy will eventually be integrated into the ordinary strategy of the destruction of the kleśas; wisdom and compassion, though developed partly by the power of the kleśas, will eventually act to destroy them. Nevertheless, this process by which the kleśas are taken up and manipulated makes better sense of Śāntideva's provocative image of transmutation than does the dominant strategy of immediate eradiation that we find elsewhere in his text.

One reason to focus on Śantideva's skillful manipulation of the kleśas is to recognize his skill as a psychologist who works over fissures of unstable energy bubbling up through a film of false conceptuality, directing illusion-like terror, hatred and greed as a means of eradicating illusion-like pain. Śāntideva, I have argued, faces a paradox of motivation; how can you begin to truly love, when all you have ever deeply known is hatred and thirst? One of the ways out of the conundrum, Sanntideva is suggesting, is to hate the hatred itself and bootstrap into compassion by transmuting craving for release into deep concern for the well-being of all.

Śāntideva's handling of poison also helps us notice his dependence upon but also contribution to some of the classic themes of Madhyamaka Mahayana philosophy. In particular, handling the kleśas can be recognized as an extension of the Mahayana doctrine of skillful means in which what is ordinarily harmful is made auspicious through the protective power of wisdom and compassion. We find also more than a hint of the tantric in Sāntideva's redeployment of negative energy for liberation, a resonance which is strengthened by his choice of the image of alchemy that itself has tantric undertones. ${ }^{45}$ All of this suggests the deep identification of samsāra and nirvana that finds its most explicit statement in Nāgārjuna's Root Verses on the Middle Way (Mūlamadhyamakakārikā 25:19). ${ }^{46}$ Sāntideva, too, I have argued, holds that the afflictive can be the liberative, and while not intended to be exhaustive, I hope to have developed some insight into the form such identifications take in his masterwork.

Acknowledgements I am grateful to Daniele Cuneo, Amod Lele and an anonymous reviewer for the Journal of Indian Philosophy for excellent written comments which have improved this essay. I also benefited from conversations with Ethan Mills, Laura Guerrero, Jeremy Martin and Will Barnes about some of the ideas presented here. The current version of this essay was influenced by an extended discussion with Richard Hayes over verse 1:10 of Śāntideva's Bodhicaryāvatāra. You can find Hayes' own reflections on this verse in Hayes (2016).

\section{Compliance with Ethical Standards}

Conflict of interest The author declares that they have no conflict of interest.

\footnotetext{
45 See also McRae (2015) for her treatment of tantric elements in Mahayana moral philosophy.

46 "There is no distinction whatsoever between saṃsāra and nirvāṇa. There is no distinction whatsoever between nirvāṇa and saṃsāra” (Nāgārjuna 2013, p. 302).
} 
Open Access This article is distributed under the terms of the Creative Commons Attribution 4.0 International License (http://creativecommons.org/licenses/by/4.0/), which permits unrestricted use, distribution, and reproduction in any medium, provided you give appropriate credit to the original author (s) and the source, provide a link to the Creative Commons license, and indicate if changes were made.

\section{References}

Anālayo. (2010). The genesis of the Bodhisattva ideal. Hamburg: Hamburg University Press.

Asanga. (1986). Asanga's chapter on ethics with the commentary of Tsong-Kha-Pa, the basic path to awakening, the complete Bodhisattva (M. Tatz, Trans.). New York: Edwin Mellen Press.

Asanga. (2001). Abhidharmasamuccaya: The compendium of the higher teaching (philosophy) by Asanga (W. Rahula, Trans.). English translation by Sara Boin-Webb. Fremont, CA: Asian Humanities Press.

Bodhi, Bhikkhu (Trans.). (2000). The Connected Discourses of the Buddha (Samyutta Nikāya). Somerville, MA: Wisdom Publications.

Brekke, T. (2002). religious motivation and the origins of Buddhism: A social-psychological exploration of the origins of a world religion. London: RoutledgeCurzon.

Brons, L. (2016). Facing death from a safe distance: Samvega and moral psychology. Journal of Buddhist Ethics, 23, 83-128.

Buddhaghosa. (1991). The path of purification (Visuddhimagga). Onalaska, WA: Pariyatti Publishing.

Cozort, D. (2005). Highest yoga tantra: An introduction to esoteric Buddhism of Tibet. Ithaca, NY: Snow Lion Publications.

Crosby, K., \& Skilton, A. (1995). Śāntideva. The Bodhicaryāvatāra. Oxford: Oxford University Press.

Davidson, R. M. (2002). Indian Esoteric Buddhism: A social history of the Tantric movement. New York: Columbia University Press.

Garfield, J. L. (2010). What is it like to be a bodhisattva: Moral Phenomenology in Sāntideva's Bodhicaryāvatāra. Journal of the International Association of Buddhist Studies,33, 333-357.

Giustarini, G. (2012). The role of fear (bhaya) in the Nikāyas and in the Abhidhamma. Journal of Indian Philosophy, 40, 511-531.

Gomez, L. (1973). Emptiness and moral perfection. Philosophy East and West,23, 361-373.

Gray, D. (2001). On supreme bliss: A study of the history and interpretation of the Cakrasamvara Tantra. PhD diss: Columbia University.

Harris, S. (2011). Does Anātman rationally entail altruism? On Bodhicaryāvatāra 8:101-103. Journal of Buddhist Ethics, 18, 92-123.

Harris, S. (2014). Demandingness, self-interest and benevolence in Śätideva's introduction to the practice of awakening (Bodhicaryāvatāra). PhD diss. University of New Mexico.

Harrison, P. (1987). Who gets to ride in the great vehicle: Self-image and identity among the followers of the early Mahāyāna. Journal of the International Association of Buddhist Studies, 10(1), 67-89.

Hayes, R. (2016). When a philosopher's stone turns gold into base metal. Sophia: International Journal of Philosophy and Traditions, 55(3), 357-380.

Jenkins, S. L. (1999). The circle of compassion: An interpretive study of Karuna in Indian Buddhist literature. $\mathrm{PhD}$ dissertaion, Harvard University.

Lele, A. J. (2007). Ethical revaluation in the thought of Sāntideva." PhD diss., Harvard University.

Matthews, B. (1983). Craving and salvation: A study in Buddhist soteriology. Waterloo, ON: Wilfrid Laurier University Press.

McRae, E. (2015). Metabolizing anger: A tantric Buddhist solution to the problem of moral anger. Philosophy East and West,65(2), 466-484.

Nāgārjuna. (2013). Nāgārjuna's middle way: Mūlamadhyamakakārikā (M. Siderits \& S. Katsura, Trans.). Boston: Wisdom Publications.

Ñānamoli, Bhikkhu (Trans.). (1977). The guide (Netti-ppakaranaṃ) according to Kaccāna Therea. London: The Pali Text Society.

Nānamoli and Bodhi (Trans.). (1995). The middle length discourses of the Buddha. Boston: Wisdom.

Pettit, J. (1999). Paul Williams: Altruism and reality: Studies in the philosophy of the Bodhicaryavatara. Journal of Buddhist Ethics, 6, 120-137.

Samuels, J. (1997). The Bodhisattva ideal in Theravāda Buddhist theory and practice: A reevaluation of the Bodhisattva-Śrāvaka opposition. Philosophy East and West.,47(3), 399-415. 
Śāntideva. (1960). Bodhicaryāvatāra of Śāntideva with the Commentary Panjika of Prajnakaramati. Edited by P.L. Vaidya. Darbhanga: India. The Mithila Institute of Post-Graduate Studies and Research in Sanskrit Learning. Digital Version by Digital Sanskrit Buddhist Canon.

Śāntideva. (1971). Sikshā-samuccaya: A compendium of Buddhist doctrine complied by Śāntideva Chiefly from earlier Mahāyāna Sūtras (C. Bendall \& W. H. D. Rouse,Trans.). Delhi: Motilal Banarsidass.

Sāntideva. (1997). A guide to the Bodhisattva way of life (Bodhicaryāvatāra) (V. Wallace \& A. Wallace, Trans.). Ithaca, NY: Snow Lion Publications.

Schmithausen, L. (2007). Nichtselbst, Leerheit und altrustische Ethik im Bodhicaryāvatāra. In K. Preisendanz (Ed.), Expanding and merging horizons: Contributions to South Asian and crosscultural studies in commemoration of Wilhelm Halbfass (pp. 551-570). Vienna: Austrian Academy of Sciences Press.

Siderits, M. (2000). The reality of altruism: Reconstructing Śāntideva. Philosophy East \& West,50(3), $412-424$.

Silk, J. (2002). What, if anything, is Mahāyāna Buddhism? Problems of definitions and classifications. Numen, 49, 355-405.

Snellgrove, D. (1959). The Hevajra Tantra: A critical study. Oxford: Oxford University Press.

Sparham, G. (1992). Indian Altruism: A Study of the Terms bodhicitta and bodhicittotpāda. The Journal of the International Association of Buddhist Studies, 15(2), 224-242.

Thurman, R. A. F. (Ed.). (2004). The universal vehicle discourse literature (Mahāyānasūtrālaṃkāra) (L. Jamspal, R. Clark, J. Wilson et al., Trans.). New York: American Institute of Buddhist Studies.

Wangchuk, D. (2007). The resolve to become a Buddha: A study of the bodhicitta concept in Indo-Tibetan Buddhism. Tokyo: The International Institute for Buddhist Studies of The International College for Postgraduate Buddhist Studies.

Wedemeyer, C. (2013). Making sense of tantric Buddhism: History, semiology, and transgression in the Indian traditions. New York: Columbia University Press.

White, D. G. (1984). Why gurus are heavy. Numen,31(1), 40-73.

White, D. G. (1996). The alchemical body: Siddha traditions in Medieval India. Chicago: The University of Chicago Press.

Williams, P. (1998). Studies in the Philosophy of the Bodhicaryāvatāra: Altruism and reality. Delhi: Motilal Banarsidass.

Williams, P. with Tribe, A. (2000). Buddhist thought: A complete introduction to the Indian tradition. New York: Routledge. 